\title{
Decolonizing agriculture in the United States: Centering the knowledges of women and people of color to support relational farming practices
}

\author{
Emma Layman $^{1}$ (1) $\cdot$ Nicole Civita ${ }^{2}$
}

Accepted: 10 January 2022 / Published online: 27 January 2022

(C) The Author(s), under exclusive licence to Springer Nature B.V. 2022

\begin{abstract}
While the agricultural knowledges and practices of Black, Indigenous, and People of Color (BIPOC) and women have shaped agriculture in the US, these knowledges have been colonized, exploited, and appropriated, cleaving space for the presently dominant white male agricultural narrative. Simultaneously, these knowledges and practices have been transformed to fit within a society that values individualism, production, efficiency, and profit. The authors use a decolonial Feminist Political Ecology framework to highlight the ways in which the knowledges of Indigenous, Black, and women farmers have been and are being colonized; a tradition that makes alternative agriculture a predominantly white space. The authors interviewed 10 BIPOC and women farmers in Colorado to understand what values and knowledges were shaping their often-appropriated agricultural practices. Three themes emerged: people, place, and patterns. By centering these values, farmers create relational agricultural practices that support the well-being of human and more-than-human beings. To support the widespread implementation of these practices, food systems practitioners must elevate the voices and knowledges of historically excluded farmers. Only then can truly just and equitable alternative agricultural practices be realized in the US.
\end{abstract}

Keywords Women $\cdot$ BIPOC $\cdot$ Situated knowledges $\cdot$ Decolonization $\cdot$ Relational agriculture $\cdot$ Feminist political ecology

$\begin{array}{ll}\text { Abbreviations } \\ \text { BIPOC } & \text { Black, Indigenous, and People of Color } \\ \text { CACR } & \text { Collective agency and community resilience } \\ \text { CO } & \text { Colorado } \\ \text { CMP } & \text { Colonial matrix of power } \\ \text { CSA } & \text { Community supported agriculture } \\ \text { ERS } & \text { Economic Research Service } \\ \text { FPE } & \text { Feminist political ecology } \\ \text { NASS } & \text { National Agricultural Statistics Service } \\ \text { PTSD } & \text { Post-traumatic stress disorder } \\ \text { US } & \text { United States } \\ \text { USDA } & \text { United States Department of Agriculture }\end{array}$

Emma Layman

emma.layman@colorado.edu

Nicole Civita

ncivita@sterlingcollege.edu

1 University of Colorado at Boulder, 4001 Discovery Drive, Boulder, CO 80303, USA

2 Sterling College, 16 Sterling Drive, Craftsbury Common, VT 05827, USA

\section{Introduction}

The agricultural knowledges and practices of women ${ }^{1}$ and Black, Indigenous, and People of Color (BIPOC) have shaped agriculture in the US; they have also been colonized, exploited, and appropriated, cleaving space for the presently dominant white male agricultural narrative. Simultaneously, these knowledges have been transformed to fit within a society that values individualism, efficiency, and profit. Would the impact of women and BIPOC's knowledges and practices be different if we, food systems practitioners, decolonized agriculture? That is, if we recognized different ontologies, worlds, and the many ways of knowing and practicing agriculture in those worlds? By centering women and BIPOC in agriculture, instead of limiting them to the periphery, the authors intend to help dissolve the dominant agricultural narrative in the US - that current systems, practices, and technologies are rooted in masculine, white, Western knowledge.

\footnotetext{
1 The term "women" will be used in this paper to include cisgender, transgender, and non-binary individuals and anyone else who identifies as a woman.
} 
The role of women and BIPOC in the development of US agriculture has been all but erased, creating an entire agrifood system that actively marginalizes these communities. It is vital to reclaim spaces for these actors. By centering past examples of BIPOC and women's knowledges as well as interviews with BIPOC and women farmers conducted by Emma Layman, the authors demonstrate a path toward decolonizing and creating a more just food system-one that values the environment, as well as the human and morethan-human beings that inhabit it. Using a decolonial feminist political ecology (FPE) framework (i.e., one that pairs situated knowledges and pluriverses) in tandem with stories from women, BIPOC, and people with intersecting identities therein, we aim to help bring these knowledges from the periphery to the center, making visible the existence of "a world of many worlds" (de la Cadena and Blaser 2018).

Before continuing, we must recognize the fictitious nature of both gender and race. However, despite their imaginary nature, these constructs have real implications for power and autonomy. Accordingly, gender and race are used in this paper to analyze how power structures impact the colonization of knowledges in-and access to-agriculture. Confronting colonial constructs and the ways they continue to shape our present is a precondition for dismantling and rebuilding equitable food systems.

\section{Situating ourselves}

Historically, white women have forced colonial systems onto women of color (Simpson 2017, pp. 95-99). As white women, we, the authors, must grapple with the potential for this research and writing to reinforce systems that steal, appropriate, and erase the knowledges of colonized peoples. In our professions, as in our lives, we must continually and critically engage with the ways our positionalities influence our work: We are financially secure, able-bodied, cisgender, white women. We have been educated and live in a society that is built on stolen lands and resists the idea of redressing that wrong. We hold advanced degrees from institutions that reify the idea of a singular and universal view of history and the world.

We come to this work from places of privilege. The inequities of the agri-food system have not dominated our personal experiences or relationships with food and land, though we study them extensively and actively engage in movements for justice. With this in mind, we have tried to critically engage with questions such as "Where does [X] theory come from? What is the context? Who generated it?... Can I use it in an ethical and appropriate way (my ethics and theirs) given the colonial context within which scholarship and publishing take place?" (Simpson 2017, p. 63). These questions have served as a starting point for ethically and conscientiously determining which knowledges to include in this paper as well as how to engage with them.

\section{The colonization of knowledge and self: understanding to dismantle the system}

\section{Uprooting a diseased system}

"Knowledge," as understood in Western society, is a direct result of the fabrication of modernity and the colonial matrix of power. The ideas of modernity and progress can be traced to the Renaissance and Enlightenment when white European men were "discovering" the one true reality (Mignolo 2011). If non-Western knowledges could not be explained by Western scientific methods, then they were considered invalid for policy, science, etc.- - this phenomenon is not a relic of the past; rather, select practitioners in every field continue to regard non-Western knowledges as less valid or advanced. Even if non-Western knowledges could (or can) be explained, credit was (and is) rarely given to the originators of these "cultural beliefs."

To operate as a modernized and civilized state, the US and other Western countries need(ed) a less civilized, less knowledgeable country or peoples against which to compare and exalt themselves. Consequently, modernity would not be possible without its darker side: coloniality (Mignolo 2011). Only by placing other civilizations in the past as savages, barbarians, or primitives were European civilizations able to claim superiority. The civilized/uncivilized dichotomy "justified" colonization because non-Western peoples could be considered less than fully human. As such, their knowledges could be discovered, extracted, resituated, redistributed, and/or discredited since acknowledging "their contribution would, in terms of the rules of research practice, be as legitimate as acknowledging the contribution of a variety of plant, a shard of pottery or a "preserved head of a native' to research" (Smith 2012, p. 63). While the rules of research practice may have shifted since the $1500 \mathrm{~s}$, the power dynamics of colonization and the resulting systems continue to dictate the lives and privileges (or lack thereof) of people living in colonized spaces.

Coined by Anibal Quijano, the patron colonial de poder or colonial matrix of power (CMP) is made up of four interrelated domains: control of the economy, authority, gender and sexuality, and knowledge and subjectivity; these domains are all supported by patriarchy and theology (Mignolo 2011, p. 9). This matrix has supported the idea of knowledge as "a commodity to be exported to those whose knowledge was deviant or non-modern according to Christian theology and, later on, secular philosophy and sciences" (Mignolo 2011, p. 13). Thus, the CMP works in tandem with 
progress and modernity to invalidate non-Western (i.e., nonwhite, non-masculine, non-Christian) worlds, ontologies, and knowledges. The CMP and Western modernity have resulted in power hierarchies with white men at the top and women of color at the bottom; a hierarchy of knowledge follows this same structure.

Severed from their originators, knowledges become and remain abstract concepts, dismembered and placed into a Western world. This process of theft and erasure of other worlds supports the fallacy of a singular reality and enables dominations. Non-Western knowledges and practices are consumed by the West-a "world-destroying machine [that] cannot fit with other worlds" (Stengers 2018, p. 86). But other worlds have not disappeared. Even in the US these worlds continue to exist, perhaps not $c o$-exist with the Western world, but exist nonetheless.

\section{Nurturing seeds of resistance and survivance}

Knowledge systems in the US must be decolonized in order to create a cosmopolitics or a place where heterogeneous ontologies, worlds, and their divergent practices can interact, collide, and do difference together (de la Cadena and Blaser 2018; Verran 2018). We offer the view that "decolonization, once viewed as the formal process of handing over the instruments of government, is now recognized as a longterm process involving the bureaucratic, cultural, linguistic and psychological divesting of colonial power" (Smith 2012, p. 101), as well as the notion that decoloniality "means both the analytic task of unveiling the logic of coloniality and the prospective task of contributing to building a world in which many worlds will coexist" (Mignolo 2011, p. 54). Decolonization includes returning land and sovereignty to Indigenous peoples (Tuck and Yang 2012), but the logic and power of coloniality must first be made undeniably visible so it can be dismantled.

FPE aims to decolonize systems by explaining "how women's knowledges and the gender division of labor" as well as "race, ethnicity and class shape individual and group access to social and natural resources and subsequent environmental changes" (Jarosz 2011, p. 308). Pairing this definition with concepts such as situated knowledges (Haraway 1988) and the existence of multiple ontologies or worlds (de la Cadena and Blaser 2018) creates a framework for exploring the numerous worlds within which agriculture operates and the varied impacts of these worlds on environment and people alike. Decolonial FPE can be used to dismantle the power associated with "heteropatriarchy [which] was normalized through colonialism and postcolonial state-craft" and instead create "counter hegemonic discourses for transformation politics" (Sultana 2020, pp. 5-6). FPE calls into question the underlying ontologies, systems, and paradigms that construct each individual's world; thus, using an FPE framework provides a unique lens through which to view agricultural practices and livelihoods. Rather than analyze the impacts of various farming methods or enterprises, FPE allows one to analyze the very structures, values, beliefs, and reasonings behind farming.

The term situated knowledges, introduced by Donna Haraway, illustrates that everyone has partial knowledge(s) based on their positionality. Recognizing situated knowledges is key to understanding the multiplicity and partiality of all knowledges: "Subjectivity is multidimensional... the knowing self is partial in all its guises, never finished, whole, simply there and original; it is... able to join with another, to see together without claiming to be another" (Haraway 1988 , p. 586). Situated knowledges are intricately linked to our ways of being - the knowledges we possess are a result of the world(s) we live in and the ways we interact and exist in those worlds. Recognizing each individual's partial knowledges allows worlds to be brought together without losing their individuality. When applied to agriculture, situated knowledges shape how people relate and interact with others, including humans, land, and other beings. Situated knowledges allow agriculture to become relational.

\section{The extraction and appropriation of agricultural knowledges}

Post-settlement agriculture-that is, agriculture practiced by colonizers upon arrival to Turtle Island-is inextricably bound in colonialism and slavery, the legacies of which continue to exclude and exploit women and BIPOC knowledges. Scholars drawing on FPE "demonstrate how women and other marginalized groups are systematically disadvantaged by conventional scientific [and knowledge] practices that exclude them as knowers, while producing knowledge that renders their experiences invisible or represents them as inferior" (Sundberg 2017, pp. 3-4). The invalidation of women and BIPOC knowledges is notable in US agriculture, where their knowledges have been essential to the success of the overall industry, but are simultaneously invisibilized to maintain power.

"The knowledge practices we (modern scholars) have at our disposal are, in turn, conditioned to reinstate themselves" (de la Cadena and Blaser 2018, p. 6). We must weed out the invasive overgrowth of colonial principles and structures in our systems and nurture the seeds of diverse ontologies that have been, and are, threatened by colonization, yet growing nonetheless.

The following sections offer an overview of the exploitation, colonization, and erasure of agricultural contributions by BIPOC and women. While the sections have been separated into Indigenous knowledges and Black knowledges, they are not mutually exclusive and, in fact, often overlap. 
Additionally, "white people" is used to reference people of European descent who benefit from white supremacy and colonial, Christian, patriarchal structures; some subset of white farmers may better center the community and environment in their practices, though infrequently to the same extent as practitioners with non-white ontologies.

\section{Indigenous knowledges}

Contrary to narratives of the US as a "wild" frontier discovered by Western "explorers," Indigenous peoples across the Americas were cultivating the earth long before the arrival of colonizers. However, Indigenous relations to the land differed (and continue to differ) from Western conceptions of human/nature relationships. At the core of Western ontology is an understanding of the world through object relationships, or that nature can be conceptualized in terms of resources and how they can be used by humans. By viewing nature, people, and other-than-human beings in this way, Western ideology supports "the idea of the world or creation existing for the purpose of human domination and exploitation" (Duran and Duran 1995, p. 15). This understanding of nature as a "repository of objectified, neutralized, and largely inert materiality that exist[s] for the fulfillment of the economic goals of the "masters' of the materials" became an even greater pillar of Western ideology during the Industrial Revolution when the West was "advancing" and the rest of the world was "falling behind" (Mignolo 2011, p. 12).

In contrast, Native American ontologies view the world as an interconnected system in which life cannot be compartmentalized into nature or human: "the Native American worldview is one in which the individual is a part of all creation, living life as one system and not in separate units that are objectively relating with each other" (Duran and Duran 1995, p. 15). Native American languages reflect this: $70 \%$ of Potawatomi words are verbs, focused on identifying relations, while "English is a noun-based language, somehow appropriate to a culture so obsessed with things" (Kimmerer 2015, p. 53). For many Native American communities, their understanding of the world is rooted in relations with the land, "land that is constructed and defined by [their] intimate spiritual, emotional, and physical relationship with it" (Simpson 2017, p. 23). This relationship is, in part, due to kinship since, "for American Indians, land, plants, and animals are considered sacred relatives, far beyond a concept of property" (Brave Heart and DeBruyn 1998, p. 62; Salmon 2000). Instead of viewing the natural world as a pantry, filled with resources for consumption, Indigenous ontologies understand other-than-human actors as entities with agency and value beyond the production of goods.

The differences between Indigenous and Western ontologies inform their respective agricultural practices. This is exemplified in Robin Wall Kimmerer's discussion of the Three Sisters:

For millennia, from Mexico to Montana, women have mounded up the earth and laid these three seeds in the ground, all in the same square foot of soil. When the colonists on the Massachusetts shore first saw Indigenous gardens, they inferred that the savages did not know how to farm. To their minds, a garden meant straight rows of single species, not a three-dimensional sprawl of abundance (2015, p. 129).

The Three Sisters are an example of companion planting, but they are more than an agricultural practice. The three crops are sisters, women, companions. Kimmerer says they should be called the Four Sisters-without the women who identified these crops as companions, and the women who continue to plant them, the other sisters would never have the chance to grow (2015, pp. 139-140). While planting corn, beans, and squash together produces greater yields of each, this practice is as much about production as it is about nutrition, social norms, and the centrality of women within Indigenous agricultural knowledges: "being among the sisters provides a visible manifestation of what a community can become when its members understand and share their gifts. In reciprocity, we fill our spirits as well as our bellies" (Kimmerer 2015, p. 134). Therefore, the Three Sistersand growing food in general-stems from an ontology that does not separate life and knowledges into disciplines or categories; instead, the Three Sisters embody Indigenous agricultural knowledges about plants and land as well as social knowledges about reciprocity and community.

Since the organic farming movement of the 1970s, companion planting has become a popular component of sustainable agriculture. American agronomists tout the productivity and benefits of the Three Sisters, but by transplanting the practice and associated knowledges into a Western scientific setting, the full meaning of "companion" is lost. While partial understandings are unavoidable, the process of Western extraction of Indigenous knowledges replicates a history of dismembering concepts, peoples, and places. Simpson explains:

Colonialism and capitalism are based on extracting and assimilating. My land is seen as a resource. My relatives in the plant and animal worlds are seen as resources. My culture and knowledge is a resource. My body is a resource and my children are a resource because they are the potential to grow, maintain, and uphold the extraction-assimilation system. The act of extraction removes all of the relationships that give whatever is being extracted meaning (Klein 2013).

Again and again, the West celebrates that which can be quantified and discards the parts that can "merely" be sensed 
or believed. In so doing, Western agronomy offers predominantly white farmers seeking sustainable or organic practices a dangerously decontextualized alternative-one that allows minor modifications of agri-capitalism but stops far short of questioning its premises. Thus, the resource-focused versus relation-focused situated knowledges of Western and Native American farmers, respectively, causes the same practice of planting corn, squash, and beans to resonate very differently.

The stark differences between Western and Indigenous ontologies are consequential. Indigenous agricultural knowledges are place-based and relational. For many Indigenous peoples, "rituals and ceremonies, the language, and, therefore, [Indigenous] thought are influenced by the lands, animals, and winds with which they live" (Salmon 2000, p. 1328). Language is "a mirror for seeing the animacy of the world, the life that pulses through all things" (Kimmerer 2015 , p. 55). Recognizing this animacy and the need for other-than-human relations allows us to "imagine the access we would have to different perspectives, the things we might see through other eyes, the wisdom that surrounds us" in such a world where all life forms are viewed as kin (Kimmerer 2015, p. 58). Western ontologies focus on extraction from these kin, who have been christened "resources." To the extent that Western agriculture can be seen as relational, the relationships are domineering at best, abusive at worst. "Heteropatriarchy captured the beast of capitalist agriculture and used it to enforce, and reinforce, its power inequalities... envisioning food and agriculture as pure matters of production and consumption, not as social, economic, and ecologic arrangements" (Leslie et al. 2019, p. 868). The pursuit of "sustainable agriculture" within the same heteropatriarchal power structures and exploitative systems of so-called "conventional agriculture" - and without restoration of situated Indigenous knowledges-risks sustaining the wrong things.

\section{Black knowledges}

Black knowledges have been specifically sought to strengthen US agriculture, and are then subsumed into a narrative of Euro-exceptionalism. While the contributions of Black farmers and farm workers post-Reconstruction have been severely undermined by systemic racism following the abolition (though arguably not the end) of slavery, Black knowledges-alongside extraordinary sacrifices and exertion-continue to underpin major portions of American agriculture.

The history of rice cultivation and enslavement in the US is a history of the erasure and expropriation of Black knowledges. For decades, scholars failed to acknowledge that certain varieties of rice had been domesticated in West Africa, independent of rice domestication in Asia. "Even though the African method of shifting land use between rice and cattle supports a complex land rotation and diversified nutritional base, the underlying rationale of the system eluded Europeans;" as a result, European observers "placed African farmers on a less evolved level within the hierarchy of agriculture, civilization, and progress" (Carney 2001, p. 48). Despite this argument that African agricultural practices were not understood by colonizers, the knowledges of enslaved African peoples were greatly used to the advantage of white plantation owners (and their white families) to build an empire (Alpern 2013).

Rice cultivation in West Africa was primarily done by women, who embodied specialized knowledge systems. Enslaved women from Africa "bound for South Carolina received a higher purchase price than in other plantation economies," due to their unique knowledges regarding cultivation, processing, and cooking of rice (Carney 2001, p. 107). While Africans were generally deemed "uncivilized" (and often, inhuman), colonists recognized and drew on the value of African women's knowledges to develop US agriculture. Nevertheless, agronomists separated and demoted "African knowledge system[s] to just bits of information, to practice, to seed exchanges, and thus to invisibility," the legacy of which has arguably impacted perceptions of Black knowledges today (Carney 2001, p. 150).

Black people have — often out of necessity — played a substantial and invisibilized role in developing US agriculture. Perhaps readers have heard of George Washington Carver and Fannie Lou Hamer, but their inclusion in academic literature related to agriculture and food studies is far less frequent than they deserve (Leslie et al. 2019; Reese 2018; White 2018). Or, when included, their contributions to the field are minimized and attributed to white or "more civilized" practitioners. For example, Dr. Booker T. Whatley's development of "Clientele Membership Clubs," or the equivalent of today's community supported agriculture (CSAs), continues to be whitewashed by the narrative that "community supported agriculture originated in Switzerland and Japan, spreading to urban areas" in the US during the 1980s (Jarosz 2011, p. 310).

Beyond the erasure of Black knowledges from agricultural practices, the contributions of visionary Black agriculturalists also have their radical edges blunted. The collectivism and liberation ideologies that gave people-power to Fannie Lou Hammer's Freedom Farm Cooperative are replaced with a convenience-conscious capitalist slogan: "Buy Local!" Similarly, community gardens were a result of discriminatory housing policies following the Great Migration. Due to racist housing policies across the US, many of the 6 million Black Americans leaving the Southeast for other regions were only able to find housing in cities. Then, in the face of urban decline in the 1960s and 1970s, "neighbors transformed trash-strewn lots into urban oases... Urban farmers of color removed rubble, planted trees, installed 
vegetable beds, and built structures for community gatherings" (Penniman 2018, p. 206). In Detroit, Black women led the "Block Beautiful" movement to improve environmental conditions in their neighborhoods (Washington 2007). Community gardens are a form of resilience, resistance, and hope. Yet, urban farming has been co-opted by white farmers and policy makers. As urban gardens have warped into a new "green" amenity, rather than spaces of community resilience, their meaning and the neighborhoods they once resided in have been decimated in the wake of ecogentrification (McClintock 2018).

These knowledges, while severed from their context and values by white practitioners, have also been passed down to Indigenous and Black descendants by blood memory. The memories, trauma, and joy of our ancestors are carried in our own bodies, our own DNA (Van der Kolk 2014; Menakem 2017). For Indigenous and Black peoples, this means they still carry the ontologies, worlds, knowledges, and practices of their people (Newman and White 2020).

\section{Gender and patriarchy in agriculture}

Women had a leading role in prehistoric agriculture. Because women were gatherers, they possess(ed) unique knowledges of plants and seeds (Howard 2003). Archaeological findings and recent research also suggest that during early agriculture, women were responsible for most of the associated labor. A 2017 study found that, "in contrast to men, rigorous manual labor was a more important component of prehistoric women's behavior than was terrestrial mobility through thousands of years of European agriculture, at levels far exceeding those of modern women" (Macintosh et al. 2017, p. 1). Higher levels of upper limb loading (used to dig ditches, carry baskets of crops, etc.) were identified among prehistoric women than semi-elite female athletes today-women were the initial power-force behind agriculture (Price 2017).

While women were likely the first farmers, many believe that agriculture birthed patriarchal structures. As societies were able to produce and consume greater quantities of foods, women's roles shifted. New diets meant women could birth and raise more children, resulting in a greater amount of time spent on domestic activities (Hansen et al. 2015). Thus, agricultural practices rooted solely in production have "a persistent negative impact on the position of women in society... Patriarchal values and beliefs-with strong origins in agriculture-have become stronger over time" (Hansen et al. 2015, p. 400).

Despite the patriarchal narrative of farming, women have continued to play significant roles in agriculture. In response to both World Wars, women were encouraged to "fight" the war at home by planting and tending to victory gardens (Gowdy-Wygant 2013). From 1943 to 1945, the
United States Department of Agriculture (USDA) Extension Service estimates that " 1.5 million nonfarm women were placed in agricultural jobs... and at least that many were hired directly by farmers" (Prater 2018). Yet even when it is evident that millions of women were and are involved in agriculture, they are rarely seen: "there aren't many pictures showing women working as farmers, and if you don't see it being done, you don't know it can be done" (Prater 2018).

Similarly, the specific contributions of women in agriculture are rarely reported. While the importance of women-led victory gardens resurfaced during the COVID-19 pandemic (see articles in The New York Times, CBS News, Good Housing Keeping, and more), how many specific female agricultural changemakers can readers name? White men's individual names line the pages of history books, but women are only referenced as a general group. The women who have shaped agriculture are excluded from agricultural narratives, or, when included, are reduced to a category.

\section{Whiteness in alternative agriculture}

Alternative agriculture is a white space. If that assertion caused discomfort, we invite you to pause for a moment of introspection with the following quote:

While the ideals of healthy food, people and land are not intrinsically white, the objectives, tendencies, strategies, the emphases and absences and the things overlooked in [alternative food spaces] make them so... the connections among property, privilege and paler skin are evident in alternative food practice (Slocum 2007, p. 526).

Nationally, 95.4\% of farm operators are white (USDA NASS 2019a). In contrast, only $1.4 \%$ of farm operators identify as Black (USDA NASS 2019b). While this includes all types of farms, this trend carries into alternative agriculture. White farmers account for $96.4 \%$ of producers on organically certified farms; Black farmers account for $0.5 \%$ (Formiga 2021). The number of Black farmers in the US peaked in 1920 at over 900,000, but intentional and systemic attempts to keep BIPOC and their knowledges on the periphery of agriculture have impacted their power in and access to all areas of the food system (Sewell 2019). BIPOC are less likely to own organic farms, operate CSAs, and purchase produce from farmers markets and CSAs than their white peers (Guthman 2008; Jarosz 2011; Slocum 2007). One study found that, nationally, "farmers' market neighborhoods are significantly more white than non-farmers' market neighborhoods" (Schupp 2015, p. 836). A USDA study noted that $74 \%$ of farmers market customers were white (Guthman 2008, p. 389). Even though a majority of shoppers are white, a survey of farmers markets in California uncovered that most market managers were not concerned 
with the ethnic diversity of customers (Guthman 2008). This can be attributed to the white narrative that people need to be consuming healthier, in-season, local, and fresh foods; as a result, "how this food is produced, packaged, promoted and sold - engages with a white middle class consumer base that tends to be interested in personal health and perhaps in environmental integrity" (Slocum 2007, p. 526). At the same time, Reese (2018) argues that alternative agriculture in predominantly Black communities (e.g., community gardens) are a form of historical self-reliance as a response to structural inequalities including limited access to land, capital, and education as well as grocery stores, farmers markets, and other food sources. Taken together, Slocum and Reese demonstrate that alternative agricultural practices are alive and well in white and Black communities, albeit with different aims. What we see often depends on where-and to whom-we look.

The erasure of BIPOC farmers and agricultural knowledges is rooted in and produced through systemic discriminatory practices that make it more difficult for farmers of color to exist, much less succeed. In the 1930s, the USDA worked to promote the idea of the white heteronormative family farm via 4-H camps (Leslie et al. 2019). Embedded in this agrarian ideal were racist and sexist practices that made it more difficult for BIPOC, women, and queer farmers to gain land access, receive agricultural loans and US Farm Bill allocations, attend land grant universities, access farm worker healthcare, and be assured safe working conditions (Leslie et al. 2019); similar ideologies continue to shape US agricultural policy via the Farm Bill (Ayazi and Elsheikh 2015). Property rights, for instance, have long been reserved for white men; then, women were able to access some of these rights via heteronormative marriages and their husbands (which continues to limit queer folx's access to land) (Leslie 2019). Because of the challenges associated with purchasing land, many marginalized groups rent land or rely on an intimate partner's non-farm income to buy land (Pilgeram and Amos 2015). While leasing can offer a solution to land access, it poses its own challenges, including uncertainties regarding long-term access and rights surrounding infrastructure. Additionally, it is well documented that the public benefits and federal financial supports offered to farmers have been disbursed in a deeply discriminatory manner (Daniel 2015). Four major class action litigations against the USDA-Pigford v. Glickman (on behalf of Black farmers), Love v. Vilsack (on behalf of female farmers), Garcia v. Vilsack (on behalf of Hispanic farmers) and Keepseagle v. Vilsack (on behalf of Native American farmers) - were prompted by decades of endemic and systematic discrimination against non-white, non-male farmers in the provision and servicing of Farm Service Agency loans (Carpenter 2012). Because the evidence so overwhelmingly demonstrated unlawful discrimination in the denial, underfunding, or ruinously delayed processing of loans designed to address the initial capital and cashflow challenges of an agricultural enterprise, these cases resulted in the largest civil rights settlements in US history. Nevertheless, in most cases, the settlement awards were too little and too late to correct the staggering losses of land, livelihoods, and economic stability for Black, female, Hispanic, and Native American Farmers.

White women have increasingly had greater access to resources, including land, capital, and education, than people of color. Women operate nearly $25 \%$ of organic farms in the US, which is double the number of conventional women farmers (Jarosz 2011, p. 307). White women who engage with alternative agriculture are often interested in farming for reasons that differ from industrial farmers. Jarosz found that white women's farming methods in the Pacific Northwest were rooted in an ethics of care; their work was "centered upon nourishing themselves and others," with "others" often including the land itself (2011, p. 308). Moreover, "in comparison to men, women within sustainable agriculture sometimes hold different values-namely quality family life and spirituality - and definitions of quality of life derived from their gender-based roles and responsibilities in the home, community, and on the farm" (Leslie et al. 2019, p. 859). Therefore, women-operated farms are associated with different ontologies, knowledges, and relations than farms managed by men.

Women, BIPOC, and women of color have their own experiences, ontologies, and situated knowledges, and thus embody different worlds. "What potentially emerge[s] from alternative food practices, then, are embodied ecologies: situated, corporeal ways of connecting differences through engaged universals" (Slocum 2007, p. 523); but for this to happen, these divergent ontologies, worlds, and knowledges must be centered in alternative food practices. The stories, experiences, and lives of marginalized farmers must be openly invited and humbly received.

\section{Growing worlds through conversation}

Alongside the histories of oppression and appropriation is an incontrovertible truth: other knowledges continue to be practiced today, creating many worlds. In a world of many worlds, some must offer more desirable social, economic, and environmental relations. Consequently, we are compelled to ask: How can the knowledges of women and BIPOC help to shape a more just alternative food system? And, how can these knowledges be brought from the margins to the center? To answer these questions, Emma Layman spoke to those who are actively tending other worlds.

Through interviews with farmers, several highly connected and overlapping themes emerged: people, places, and patterns. People and places will be explored in greater 
Table 1 Number of participants by category

\begin{tabular}{lll}
\hline & Women & Men \\
\hline BIPOC & 2 & 2 \\
White & 6 & 0
\end{tabular}

The above table shows the number of participants separated by how farmers self-identified their race and gender

detail individually, then discussed in the context of patterns and cycles; together, these themes elevate the possibilities for practicing farming as relational, supporting the creation of more just practices.

\section{Participants and methods}

In March and April of 2021, 10 farmers were interviewed. The small study size was, in part, a consequence of conducting this research during the COVID-19 pandemic. The pandemic imposed spatial constraints; only farmers in the Denver metropolitan area and Boulder, Colorado (CO) were eligible for participation. In addition, the research was an independent graduate study, developed in response to heightened racial discourse and the unjust working conditions of essential workers during the pandemic. The study occurred within the time constraint of a single semester; thus, the authors were unable to secure funding to pay farmer-respondents for their time. However, with alternative economics in mind, Emma Layman offered to barter her labor and farming skills in exchange for the farmers' time. Several farmers accepted this offer. While the authors were aware that an unfunded study would likely result in a small sample size, they agreed it was worthwhile to elevate the voices and knowledges of BIPOC and women farmers in a discourse that continues to downplay their existence, legitimacy, and contributions.

The term "farmer" was used to include any person who is currently or was recently farming, regardless of whether or not they owned land. The size of their operation and the amount of time they had been farming did not limit participation. Farmers ranged in age from late $20 \mathrm{~s}$ to early 40 s. Farmers who identified as women accounted for $80 \%$ of participants and $40 \%$ identified as BIPOC, but only $20 \%$ identified as women of color (Table 1). A majority of participants were white women.

Initially, 24 farmers were contacted. Of the 12 white women farmers contacted, six agreed to participate while only three of the 12 BIPOC farmers agreed. Several BIPOC farmers responded that they were interested in participating but could not commit time to an unpaid study. One woman of color stated that she knows BIPOC farmers who spend 10-15 $\mathrm{h}$ a week educating others about their experiences through unpaid opportunities. Her dedication to building a viable business necessitates that her time not be offered for free. Thus, the inability to pay farmers for their time limited who could afford to be a participant. In and beyond agriculture, women, BIPOC, and especially women of color are frequently undercompensated for their time, skills, and knowledges. Securing funds to support participation in future research is a priority for the authors. Similarly, the authors hope their work will inspire more scholars and pracademics to secure funding for further research of this kind and be better positioned to compensate BIPOC and women farmers for sharing their time and knowledges.

Each farmer was interviewed for a minimum of an hour and a half, separated into two interviews. The first interview served as an introductory meeting, during which extensive written notes were taken. Farmers attended a one-on-one 30-min virtual meeting, sharing information about their journey into farming. The second (semi-structured, audiorecorded) interview lasted an hour and took place on the participants' farms in a COVID-preventative manner. The purpose of this interview was to discuss the participants' farming in greater detail, focusing on how their identity may have impacted their farming experiences. Information about how values and knowledges shaped farmers' relationships to the land was sought. Recordings were transcribed; then coded using MAXQDA 2020 to run a systemic qualitative content analysis. Recurring themes and concepts were identified. The primary coding analysis tool used was a summary of code (or theme) frequencies. This analysis of code then allowed for a simplified identification of the same themes in a word cloud. Finally, farmers were invited to a virtual meeting during which study results were shared and questions were addressed. To maintain anonymity, farmers referenced in this paper will be referred to by their first initial, or last initial to avoid repetition.

\section{Results: what is farming?}

Interviews began with a seemingly simple question: what is farming? Answers included "community," "life," and "everything," making it clear that farming is much more than an agricultural practice. Farmers were then asked: what values shape your farming practices? Because "it is the values, and not the organizing principles of the system, that determine potential impacts of agricultural sustainability" (Jones and Tobin 2018, p. 70), special attention was given to values and concepts that were repeated at higher frequencies than others. The top 25 most used words are represented in the word cloud shown in Fig. 1.

The 25 words hold significant meaning individually, but their relations are even more telling. Words such as "we," "family," and "community" are people-focused, while words like "farm," "soil," and "land" are place-based. Other words 


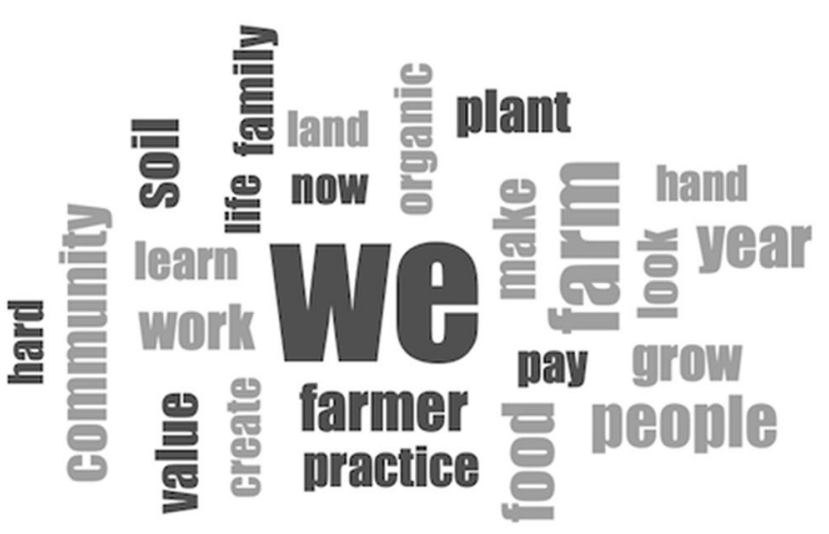

Fig. 1 What is farming? The above word cloud illustrates the frequency of words used by farmers to define farming and the values that inform this definition. The top 10 words used to describe farming and associated values were: we, farm, people, food, year, community, farmer, soil, work, make, plant, and value. To reduce redundancy, words were lemmatized (e.g., "growing" and "grows" were grouped into the word "grow")

including "life," "year," "grow," and "learn" are cyclical; all of these words evoke patterns or recurring changes over time. These three themes (people, places, and patterns) reveal farming as something that centers humans, otherthan-humans, and continual learning and adapting. In contrast, agriculture rooted in Western ontology is primarily concerned with production, efficiency, and profit.

\section{Discussion: farming as a people-, place-, and pattern-centered practice}

\section{People: the hands that sustain us}

Farming is inherently social-it connects people through food. However, conversations with farmers made it clear that the links between people and farming are too often invisibilized. This erasure is especially true when the people growing food are BIPOC or women. The social aspect of farming has also become increasingly limited as agriculture is relegated to the physical periphery of society, literally placing agriculture and farmers out of sight. Many people growing food in the US are intentionally excluded from the predominant agricultural narrative; their exclusion as actors presages the exclusion of their knowledges and skills as valuable. Farmers in this study were aware of this erasure and were working to (re)center people in agriculture by elevating: (1) the key role of farm workers and the specialized knowledges they possess and (2) the importance of building reciprocal relations with other farmers and the broader community.

Western individualism and capitalism have minimized the contributions and needs of people in agriculture. Instead, agriculture has become a product-motivated industry, relying on small margins and exploitation. Far too often "it's farm workers that are paying the price" (Farmer M) by working long, physically taxing hours for minimum wages with little to no worker protections or rights. Many interviewees experienced this mistreatment firsthand, and averred that the mistreatment was tied to their gender or race. Though Farmer $\mathrm{H}$ believes it is different for white workers asserting that: "white farm workers are probably already making above minimum wage" and "working on different kinds of farms and different settings or unpaid internships [than BIPOC workers] because they have [the] resources to take those positions." Several farmers were hoping to combat this issue by refusing to host volunteers on their farms, explaining that "people who do this work should be compensated and paid for it... [we're] pushing back a little on how agriculture was built on the exploitation of labor and don't want to be a part of it, even if it feels insignificant" to have volunteers farm for a few hours a week (Farmer H). Farmer A noted that actors in sustainable agriculture "talk a lot about their biodiversity, and not a lot about using free labor, [instead] disguising it as education." There was a keen awareness that agriculture in the US was shaped by free (enslaved) labor and a sense that unpaid agricultural labor, even when consensual, discounts the true value of farming and food, carrying negative implications for paid farm workers.

An estimated 1.2 million people are hired each year to work on farms and ranches in the US, with a majority of those being immigrant laborers (USDA ERS 2020). According to the USDA, $50 \%$ of all migrant farm workers are undocumented; some say this number is closer to $75 \%$ (Jordan 2020). The US agricultural workforce is predominantly workers of color. Migrant workers perform essential work, but are mischaracterized as unskilled laborers. Farmer J, a Japanese American woman, said:

I feel like [migrant farm worker] voices are extremely underrepresented and the fact that the major narrative in politics is that they're considered unskilled laborers is the most insulting thing to me as a farmer... because I don't think I've learned as much about how to farm and how to be a good farmer as I have learned from all of the migrant farmers I have ever worked with or have had the pleasure of working near.

Migrant farm workers, often from Indigenous communities, are the backbone of agricultural knowledges and practices, but their contributions continue to be exploited by white narratives. Regenerative agriculture, a recent buzzword with varying definitions related to lowering the environmental and/or social impacts of agriculture (Newton et al. 2020), is founded on Indigenous practices, yet has been white washed. Farmer R, who identifies as a Latino immigrant, shared his experience: 
Sometimes I have conversations or meetings with farmers in the regenerative ag[riculture] movement and I use the term Indigenous practices and they have no idea what I'm talking about... That's a huge problem. You can't monetize a farming technique that's been instituted for so long and just now getting the recognition that it needs because it's coming from a different community with power.

Farmer J's view of regenerative agriculture was similar in that she believes "it's just that continuing narrative of centering whiteness in agriculture... The regenerative lingo happens because other voices are being suppressed." Farmer $\mathrm{J}$ argues that "within the media, they're not really bringing in other voices when they make these films [like Kiss the Ground and Big Little Farm] and so I think they need to be called out on cherry picking stories just because they will make money." Similar to companion planting, this is an example of how Indigenous practices have been removed from their associated ontologies, values, and people and instead placed in a Western context where profit is a core motivator, even in alternative agriculture.

Women and BIPOC farmers are increasingly disrupting notions of individualism by forming co-operatives, collectives, and coalitions with other farmers as well as with the broader community. The shift to community-centered farming appears prompted by the systemic challenges faced by women and BIPOC when entering agriculture as well as the constant need to adapt practices to better nurture the land and our bodies, and the desire to build deeper, nontransactional, relations with customers.

Of the 10 farmers interviewed, only two were able to farm independently, without relying on the financial support of a partner (romantic or platonic). Four interviewees were able to farm only because their spouse or partner provided a non-farming income. Another four were only able to farm because they had a business partner who could help acquire loans and/or provide other resources. One of the farmers who did not rely on a business partner or spouse to farm instead depended on community support and donations. Nearly every farmer said that the greatest barrier to farming was land access, specifically having the capital to purchase or lease land, and that without their partners they would not have a property to farm. Approaching farming through collaboration and partnerships allowed these farmers to overcome barriers.

Farmers also spoke about the importance of exchange within the farming community, explaining that their own practices developed from conversations with farmers. Farmer $\mathrm{H}$ shared that the practices she and her partner use "evolve a lot as [they] meet new farmers and read new science;" they make "sure that [they're] really open to continual learning, and that [they] progress as [they] learn more."
Farmer L echoed that she "depend[s] a lot on the wisdom of others," and that the ways she farms have been heavily informed by farmers she has worked for previously. Others explained how their farming community has supported them in times of need by providing seedlings after a hail storm or by sharing knowledges related to ditch irrigation. The importance of the farming community mirrors White's work on agricultural resistance and co-operatives among Black farmers which she has developed into a framework called collective agency and community resilience (CACR) (2018). Thus, the values animating current day collaboratives and collectives are also present in Black ontologies related to farming in the US - they are representations of survivance and care.

Farmers also reported support and reciprocity from customers and community members, beyond transactions. For Farmer J, selling food to customers "doesn't really feel entirely like an exchange of money, it just feels like a complete exchange of support." She has found this to be an interesting way to engage in community because "not focusing on the dollar has actually been more rewarding than anything else." Community was cited by other farmers as the only reason farming was possible and as the primary reason to even begin farming (Farmer W and Farmer S).

The relationships that farmers build with each other and their communities can be traced back to the values that inform their practices. Farmer R shared that he and his business partner "value social equity, justice, food, autonomy, self-sufficiency, the commons, the collective, collaboratives, [and] co-operatives;" he strives to apply "the values that [he] grew up with in terms of mutual aid and reciprocity within [his] own family" to a business setting. Similarly, Farmer $\mathrm{S}$ defined farming in terms of people, saying that being a farmer means having a tight knit community. At the core of relational agriculture are trust and reciprocity, caring for one another (Trivette 2017); for many farmers, this community extends beyond people.

\section{Places: the ground we touch}

Just as farming is inherently social, it is fundamentally place-based. Farmers must adapt practices to the land and the hyper-local climates they cultivate. As a result, land, soil, earth, and place were common topics during interviews. Farmers talked about place both in relation to farming practices and in relation to history, trauma, and healing.

A core value of many farmers was to improve soil quality through organic, no till, and other environmentally friendly practices. Therefore, many use little to no machinery and instead rely on hand tools or their own hands. Physically touching and interacting with a place every day creates a unique relationship that most Americans likely do not experience. Farmer N explains this relationship vividly: "You 
have to put your hands in the soil more, you have to get closer to the plants to weed and look at the bugs, or look at the holes in your plants, or look at how beautiful they are... you're forced to spend more quality time with your plants."

Close proximity attunes farmers to the needs of their land and plants. For Farmer J, this is a value she was taught growing up: "I was raised more in the mentality of 'respond to what nature is giving you and then go from there' because if you limit your responses to something that is traditional or expected, I think that's why a lot of farms fail." Farming practices must be highly place-based, constantly changing to a place's needs. However, this requires the ability to view agricultural knowledge as a process of continual learning rather than a set destination. Several farmers noted that the white men with whom they have worked did not view knowledge this way and were resistant to change, even when the land made it clear that practices-in-use were not working.

Farmer $\mathrm{K}$ described the importance of place in terms of seeds; to really belong to a place for her means to belong from the core, from the start. The beginning of a farm, she observed, lies in the seeds. Farmer K "would eventually like to learn how to save seeds and have them adapt to this place, and this land." Because seeds carry the stories of a specific place, farmers have the opportunity to listen and grow with those seeds and that land to develop better practices.

Farming binds people and place, but even without farming, the two are inseparable. Certainly, place plays a key role in who we are as individuals and communities, but we equally play a role in who or what certain places are. We pass histories and cultures generationally; the land carries these stories too. Trauma and pain are held in US soils: internment camps, violent massacres, and unmarked mass graves stain the earth, in addition to the physical damage caused by harmful land management. In the words of Farmer M, "we're living in a PTSD society... this whole country was founded off the backs of people of color and stolen land." While some may find it hard to imagine that these traumas are stored in the land and can be communicated to us, a growing number of farmers use biodynamic practices to relate to soil as a spiritual entity (Pigott 2020). Interacting closely with the land thus provides an opportunity for communication.

Several of the farmers interviewed alluded to land as an actor and discussed energy exchanges with it. For Farmer $\mathrm{M}$, farming can cause anger, which she attributes to the pain in the earth, the pain from a difficult upbringing as a queer woman, and the pain that she has experienced as a farm worker. When she farms, she feels the energy of the earth and some days she embodies that energy. Farmer K also expressed interacting with land as an entity: "Every time I would go to use my BCS [a walk-behind tractor], it would break. And every time I was like, 'I'm sorry Earth, I'm really sorry, but this is what I've chosen to do,' and then it would break... And finally, I was like 'Okay, I've learned this lesson 10 times. I'll stop putting metal in you, at a very violent, fast pace." Farmer $\mathbf{J}$ shared that farming is "how I process a lot of my trauma... I can have a conversation with the soil and it can tell me its woes, and I can tell it my woes. I mean, it's something that has been here longer than we have and it'll be here long after we're here and there is definitely an energy exchange that happens for me."

These responses demonstrate that relational agriculture extends beyond human relationships to include relationships with the land and the other-than-humans that inhabit agricultural spaces, including spirits, plants, animals, rocks, and more. This animate form of relationality echoes feminist political ecologists like Kimmerer, who has noted that young people instinctively connect with other-than-human entities: "Toddlers speak of plants and animals as if they were people, extending to them self and intention and compassionuntil we teach them not to... When we tell them that the tree is not a who, but an it, we make that [tree] an object; we put a barrier between us, absolving ourselves of moral responsibility and opening the door to exploitation" (2015, p. 57). The responses from Farmers $M, K$, and $J$ demonstrate how a more animist approach to agriculture may restrain tendencies toward exploitation and offer opportunities for regeneration of more than just soil or ecosystems, but also of the spirit.

\section{Re-membering: a framework of people, place, and patterns}

From seasonal changes in weather to the intensity of work required of farmers, farming is full of patterns. It is the cycle of life from a seed to a plant and to seed and earth again; it is about giving and taking, about patterns of reciprocity. A mediation and meditation between people and places, year after year. These ideas are central to the participants' understandings of farming.

As a cyclical activity, past knowledges are deeply embedded in farming and reemerge every season. These knowledges are held in seeds, in the land, and in our own bodies; but can we, or do we, re-member them? Re-membering is both the ability to recall people, places, and patterns in the common understanding of the word and the ability to re-include people, places, and patterns as core members and actors within agriculture. Perhaps the lack of these rememberings has disrupted natural cycles and contributes to destructive agricultural practices.

When people and place are considered essential actors, then reciprocity can extend beyond the community of producer/customer typically imagined and instead include entire systems. Farmer R explained how such a cycle or pattern of reciprocity operates in practice: "We take care of the plants so they can take care of our health, so that we 
can then take care of our community, and then our community supports what we're doing. So, it's this trifecta of different ways that we mutually support one another." Similarly, Farmer $\mathrm{N}$ believes that "farming is a relationship, it's like a cycle of life... You have a relationship with your plants." As farmers provide care for plants, those plants provide nourishment for farmers and their communities.

Farming and food can nurture bodies and communities, but if people and places are not centered in agricultural practices a vicious cycle of exploitation can occur. For example, the months-long high season workload exhausts, but the off season provides a period of reflection and restoration. Farmers firmly connected seasonality with impacts on their well-being, noting that farming that does not offer a break creates an unhealthy pattern. Likewise, if place is not valued, it is easier to employ practices that destroy environments. The seasonality of farming therefore allows farmers to take lessons from each year and adapt practices to create a more sustainable-potentially healing-cycle focused on people and place, instead of a destructive one centered on maximizing production and profit.

Many authors are exploring the role farming can play in healing historical and personal traumas (Cacciatore et al. 2020; Gorman 2017; Penniman 2018). Five farmers shared that the cycles and repetitions of farming helped them work through traumas, including separation from a long-term partner, health issues, racist hate crimes, rape, and death of a parent. The other five participants did not share particular experiences that they had worked through, but still shared that farming provided a space for healing. Following are farmers' experiences with farming as a healing practice:

- Farmer J: "I have come to farming for many different reasons and one of them actually is just having a connection with the earth and I do feel like it's extremely healing for me personally, especially lately with all of the anti-Asian hate crimes happening."

- Farmer K: "Having something to care for outside of myself was very helpful... I can take care of plants and then feed other people, that has been a very healing process... Farming has always been a very grounding activity."

- Farmer L: "I don't care how old you are, it is still magical to put a seed in the ground and have it come up and then have it produce a thing... It's such a mysterious thing every time it happens, so I think even more than the environment itself, the act of growing stuff is therapeutic for people."

- Farmer M: "I think [farming] is ancestral and it's intuitive. And that's where the healing comes. We're mammals, we're supposed to be working out with the land, and the plants, and in the soil, and in the sun."
- Farmer N: "I think intimacy with the plants-it's the touching, the smelling, the seeing, the tasting... You get to use all of your senses and it just creates this serene moment. And ultimately, by gently touching on all of those... it's therapeutic. Just that whole experience, it's peaceful."

- Farmer S: "I don't know what it is about putting your hands in dirt, but it feels good. I've tried some other things too, hydroponic stuff and other things, but it's just not as satisfying and not as healing... Being able to connect with people over food has been super fun. That part of it has been really healing too."

Engaging in a practice that connects people and place over time, whether seasonally or through memories held in our bodies and the earth, creates a space for healing and repairing disconnections. While the farmers listened to in this study hold different knowledges and values than other BIPOC and women farmers in the US, they each unify themes of people, places, and patterns in their practices. If we want to support truly just farming in the US, they-and those with similar knowledges, values, and ways of being in the world-must be centered in agriculture. This, of course, is not unique to agriculture or food systems. Within the broader environmental justice movement, the most promising solutions involve critical appraisal and displacement of Western ontologies and values. Whereas solutions that stem from situated Western knowledges are likely to reinscribe harm to BIPOC communities (McGregor et al. 2020), indigenous-led environmental justice movements that center the humans and other-than-humans that make up non-Western worlds offer an opportunity to shift paradigms before merely altering practices (Ulloa 2017). Under these alternate paradigms, which are simultaneously attentive to people, places, and patterns of interaction-values of reciprocity, interdependence, and collective care have the opportunity to rise and displace colonial and industrial era preoccupations with extraction and transaction.

\section{Conclusion: continuing to seed and see other worlds}

As a nation, an industry, a community, we must value the people, land, and patterns of reciprocity, learning, and growth present in agri-food systems. We must elevate the voices of women and BIPOC in agriculture and listen without the urge to appropriate them as our own. We must recognize the presence of situated knowledges in every body, being, and place as well as the pluriverse of understandings and ways of being in worlds that emerge in the gathering.

The white agricultural narrative in the US is not the only one, it is merely a monocultural story that gets 
plowed, planted, machine harvested, and replanted across vast swathes of the American agricultural imaginary. This narrative, the practices it preferences, and the world it remakes season after season take root only because it gets re-seeded. The cultivation of alternatives in terra agricola requires celebration of other worlds through the centering of diverse ontologies, values, and situated knowledges. Replacing Western notions of singularity with multiplicities, collectives, and systems will help to decolonize agriculture and center the voices of women and BIPOC in and towards a more just food system.

Acknowledgements First and foremost, the authors would like to thank the ten farmers who participated in the study, engaged in worldbuilding conversations, and who made this research possible. We would also like to extend gratitude to Mara J. Goldman and Natalie Avalos for inspiring a deeper reflection into the ways ontologies, knowledges, colonization, and healing relate to alternative agriculture.

\section{References}

Alpern, S.B. 2013. Did enslaved Africans spark South Carolina's eighteenth-century rice boom? In African ethnobotany in the Americas, ed. R. Voeks and J. Rashford, 35-66. New York: Springer.

Ayazi, H., and E. Elsheikh. 2015. The US farm bill: Corporate power and structural racialization in the United States food system. Berkeley: Haas Institute, University of California Berkeley.

Brave Heart, M.Y.H., and L. DeBruyn. 1998. The American Indian Holocaust: Healing historical unresolved grief. American Indian and Alaska Native Mental Health Research 8 (2): 60-82.

Cacciatore, J., R. Gorman, and K. Thieleman. 2020. Evaluating care farming as a means to care for those in trauma and grief. Health and Place 62: 1-9.

Carney, J.A. 2001. Black rice: The African origins of rice cultivation in the Americas. Cambridge: Harvard University Press.

Carpenter, S. 2012. The USDA discrimination cases: Pigford, in re Black farmers, Keepseagle, Garcia, and Love. Drake Journal of Agricultural Law 17 (1): 1-35.

Daniel, P. 2015. Dispossession: Discrimination against African American farmers in the age of Civil Rights. Chapel Hill: The University of North Carolina Press.

De la Cadena, M., and M. Blaser. 2018. Introduction. In A world of many worlds, 1-22. Durham: Duke University Press.

Duran, E., and B. Duran. 1995. Native American postcolonial psychology. Albany: State University of New York Press.

Formiga, A. K. 2021. Statistics on ethnicity and race on organic farms in the United States. eOrganic. https://eorganic.org/node/34147. Accessed 5 Dec 2021.

Gorman, R. 2017. Smelling therapeutic landscapes: Embodied encounters within spaces of care farming. Health and Place 47: 22-28.

Gowdy-Wygant, C. 2013. Cultivating victory: The women's land army and the victory garden movement. Pittsburgh: University of Pittsburgh Press.

Guthman, J. 2008. 'If they only knew': Color blindness and universalism in California alternative food institutions. The Professional Geographer 60 (3): 387-397.

Hansen, C.W., P.S. Jensen, and C.V. Skovsgaard. 2015. Modern gender roles and agricultural history: The Neolithic inheritance. Journal of Economic Growth 20: 365-404.
Haraway, D. 1988. Situated knowledges: The science question in feminism and the privilege of partial perspectives. Feminist Studies 14 (3): 575-599.

Howard, P. 2003. The major importance of 'minor' resources: Women and plant biodiversity. In International Institute for Environment and Development, Gatekeeper Series. London: IIED.

Jarosz, L. 2011. Nourishing women: Toward a feminist political ecology of community supported agriculture in the United States. Gender, Place, and Culture 18 (3): 307-326.

Jones, K., and D. Tobin. 2018. Reciprocity, redistribution and relational values: Organizing and motivating sustainable agriculture. $\mathrm{Cur}$ rent Opinion in Environmental Sustainability 35: 69-74.

Jordan, M. 2020. Farmworkers, mostly undocumented, become 'essential' during pandemic. New York: New York Times.

Kimmerer, R.W. 2015. Braiding sweetgrass: Indigenous wisdom, scientific knowledge, and the teachings of plants. Minneapolis: Milkweed Editions.

Klein, N. 2013. Dancing the world into being: A conversation with Idle No More's Leanne Simpson. Bainbridge Island: Yes Magazine.

Leslie, I.S. 2019. Queer farmland: Land access strategies for smallscale agriculture. Society and Natural Resources 32 (8): 928-946.

Leslie, I.S., J. Wypler, and M.M. Bell. 2019. Relational agriculture: Gender, sexuality, and sustainability in US farming. Society and Natural Resources 32 (8): 853-874.

Macintosh, A.A., R. Pinhasi, and J.T. Stock. 2017. Prehistoric women's manual labor exceeded that of female athletes through the first 5500 years of farming in Central Europe. Science Advances 3 (11): $1-12$.

McClintock, N. 2018. Cultivating (a) sustainability capital: Urban agriculture, ecogentrification, and the uneven valorization of social reproduction. Annals of the American Association of Geographers 18: 579-590.

McGregor, D., S. Whitaker, and M. Sritharan. 2020. Indigenous environmental justice and sustainability. Current Opinion in Environmental Sustainability 43: 35-40.

Menakem, R. 2017. My grandmother's hands: Racialized trauma and the pathway to mending our hearts and bodies. Las Vegas: Central Recovery Press.

Mignolo, W.D. 2011. The darker side of Western modernity: Global futures, decolonial options. Durham: Duke University Press.

Newman, C. and R. White. 2020. Blood memory and relational food systems. Indigenize! A Growing Culture. https://www.youtube. com/watch?v=dEzguYzq2ec. Accessed 1 May 2021

Newton, P., N. Civita, L. Frankel-Goldwater, K. Bartel, and C. Johns. 2020. What is regenerative agriculture? Review of scholar and practitioner definitions based on processes and outcomes. Frontiers in Sustainable Food Systems 4: 1-11.

Penniman, L. 2018. Farming while Black: Soul Fire Farm's practical guide to liberation on the land. White River Junction: Chelsea Green Publishing.

Pigott, A. 2020. Hocus pocus? Spirituality and soil care in biodynamic agriculture. Environment and Planning E: Nature and Space 4 (4): $1665-1686$.

Pilgeram, R., and B. Amos. 2015. Beyond 'inherit it or marry it': Exploring how women engaged in sustainable agriculture access farmland. Rural Sociology 80 (1): 16-38.

Prater, L. F. 2018. A history of 'women's work'. Successful Farming, 30 May.

Price, M. 2017. Strong women did a lot of the heavy lifting in ancient farming societies. Washington, D.C.: Science Magazine.

Reese, A.M. 2018. 'We will not perish; we're going to keep flourishing': Race, food access, and geographies of self-reliance. Antipode 50 (2): 407-424.

Salmon, E. 2000. Kincentric ecology: Indigenous perceptions of the human nature relationship. Ecological Applications 10 (5): $1327-1332$. 
Schupp, J.L. 2015. Just where does local food live? Assessing farmers' markets in the United States. Agriculture and Human Values 33: 827-841.

Sewell, S. 2019. There were nearly a million black farmers in 1920. In Why have they disappeared? London: The Guardian.

Simpson, L.B. 2017. As we have always done: Indigenous freedom through radical resistance. Minneapolis: University of Minnesota Press.

Slocum, R. 2007. Whiteness, space and alternative food practice. Geoforum 38: 520-533.

Smith, L.T. 2012. Decolonizing methodologies: Research and Indigenous peoples. New York: Zed Books Ltd.

Stengers, I. 2018. The challenge of ontological politics. In A world of many worlds, ed. M. de la Cadena and M. Blaser, 83-111. Durham: Duke University Press.

Sultana, F. 2020. Political ecology I: From margins to center. Progress in Human Geography 45: 156-165.

Sundberg, J. 2017. Feminist political ecology. In The international encyclopedia of geography, ed. D. Richardson. Hoboken: Wiley Blackwell Association of American Geographers.

Trivette, S.A. 2017. Invoices on scraps of paper: Trust and reciprocity in local food systems. Agriculture and Human Values 34: 529-542.

Tuck, E., and K.W. Yang. 2012. Decolonization is not a metaphor. Decolonization: Indigeneity, Education and Society 1 (1): 1-40.

Ulloa, A. 2017. Perspectives of environmental justice from Indigenous peoples of Latin America: A relational Indigenous environmental justice. Environmental Justice 10 (6): 175-180.

USDA Economic Research Service (ERS). 2020. Farm Labor. https:// www.ers.usda.gov/topics/farm-economy/farm-labor/\#links. Accessed 5 Dec 2021.

USDA National Agricultural Statistics Service (NASS). 2019a. 2017 Census-Farm producers. https://www.nass.usda.gov/Publicatio ns/Highlights/2019/2017Census_Farm_Producers.pdf. Accessed 5 December 2021

USDA National Agricultural Statistics Service (NASS). 2019b. 2017 Census-Black Producershttps://www.nass.usda.gov/Publicatio ns/Highlights/2019/2017Census_Black_Producers.pdf. Accessed 5 Dec 2021.

Van der Kolk, B. 2014. The body keeps the score: Brain, mind, and body in the healing of trauma. New York: Penguin Books.

Verran, H. 2018. The politics of working cosmologies together while keeping them separate. In A world of many worlds, ed. M. de la Cadena and M. Blaser, 112-130. Durham: Duke University Press.

Washington, S.H. 2007. Mrs. Block Beautiful: African American women and the birth of the urban conservation movement of
Chicago, IL, 1917-1954. In Land and power: Sustainable agriculture and African Americans, ed. J.L. Jordan, E. Pennick, W.A. Hill, and R. Zabawa, 133-152. Waldorf: Sustainable Agriculture Research and Education.

White, M.M. 2018. Freedom farmers: Agricultural resistance and the Black freedom movement. Chapel Hill: The University of North Carolina Press.

Publisher's Note Springer Nature remains neutral with regard to jurisdictional claims in published maps and institutional affiliations.

Emma Layman is an innovator who believes that creative, communitycentered solutions in food and agriculture have the power to transform the world. With a BA in Environmental Studies from the University of North Carolina at Chapel Hill, she was first drawn to agriculture with a climate-focused approach. She has since worked on a variety of farms and experienced the innumerable intersections between food systems and injustices. Her focus within agriculture shifted to the connections between farming and food justice while completing the Masters of the Environment program at the University of Colorado at Boulder, where her scholarship centered on systems thinking, narrative storytelling, and sustainable food systems. She continues to pursue work and service that question systemic injustices and contribute to more equitable and life-creating food cultures.

Nicole Civita JD, LL.M. is a food systems transformation agent, educator, ethicist, and attorney. Her approach to fostering change in and through food is grounded in systems thinking and repair, attentive to relationships of care and reciprocity, and framed by comprehensive law and policy knowledge. She has extensive experience leading multi-stakeholder, community-based projects to support the development of vibrant and resilient place-based agroecological food systems, systems-aware policies, and alternative learning networks. Her scholarship and service explore ethical dilemmas related to food, investigate and resist the often-entwined exploitation of laborers, other species, and the environment in food systems, and suggest paradigm shifts for policy-makers to advance food justice. Nicole is the Vice President for Strategic Initiatives at Sterling College, where she also directs the EcoGather Initiative, and a founding co-convener of Project Protect Food Systems Workers. 